\author{
Tamás Székely \\ https://orcid.org/0000-0002-0254-9190 \\ Herder Institute, Marburg \\ Szilveszter Csernus-Lukács \\ https://orcid.org/0000-0003-1053-4113 \\ Herder Institute, Marburg
}

\title{
SECURING OWN POSITION: CHALLENGES FACED BY LOCAL ELITES AFTER THE AUSTRO-HUNGARIAN COMPROMISE*
}

\begin{abstract}
The multi-ethnic regions of the Habsburg Monarchy became increasingly perceived as places of instability and insecurity after the rise of competing national movements in the mid-nineteenth century. The antagonism between local national elites culminated after the Austro-Hungarian Compromise of 1867, as all pursued a course aimed at securing a favourable position. As actors of security, the local elites often and typically declared themselves and their respective nations to be existentially threatened and therefore with a legitimate claim to survive the challenges brought on by modern times. To investigate the security dilemmas of the local elites in two different regions of Austria-Hungary - namely in three city municipalities in BácsBodrog county in Southern Hungary; and in Vas, Sopron and Moson counties in western Hungary - this study combines methods of historical discourse analysis

* This paper was written as part of a DFG Collaborative Research Centre/ Transregio 138 subproject at the Herder Institute in Marburg, Germany, entitled 'Discourses on the Rights of Minorities and Majorities in East Central Europe in the 19th and 20th Century'. The case study of western Hungary was written by Tamás Székely, whereas the case study of southern Hungary by Szilveszter Csernus-Lukács. The introduction and conclusion of the paper are a joint effort by the two authors. The case study no. 2 was supported by The Únkp-19-3-Szte New National Excellence Program of The Ministry For Innovation And Technology.

For more, see https://www.herder-institut.de/projekte/laufende-projekte/ versicherheitlichung-und-diskurse-ueber-rechte-von-minderheiten-und-mehrheitenin-ostmitteleuropa-im-19-und-20-jahrhundert.html; more information on the collaborative research centre: https://www.sfb138.de.
\end{abstract}


with approaches taken from security and nationalism studies as well as regional and local history.

Keywords: security, securitisation, nationalism, minorities, Hungary, AustriaHungary, Habsburg empire

\section{I \\ INTRODUCTION}

Security is a shared "feeling of the individuals, the society and the state which is being created by the rule of law", at least according to a popular turn-of-century Hungarian encyclopaedia. ${ }^{1}$ In our co-authored paper, we are going to adopt this particular feeling of security, with a special focus on the local elites in two distant regions of AustriaHungary. One hears about security more and more nowadays, but it is quite difficult to imagine what feeling(s), meaning(s) and function(s) were attached to this word in historical times, such as the AustroHungarian era. ${ }^{2}$

The multinational regions of the Habsburg monarchy became increasingly perceived as places of instability and insecurity after the rise of competing national movements in the mid-nineteenth century. Depending on the different perspectives, these regions came to be conceptualised and imagined as places suffering from insufficient administration and endangered by potential ethnic or social conflicts. However, after decades of constitutional experiments in the Habsburg monarchy, in 1867 a dualistic state was established which achieved relatively long-term stability. ${ }^{3}$ As a result of the famous Compromise pact between Emperor Franz Joseph and the Hungarian elites, the sovereignty of the Kingdom of Hungary was restored.

${ }^{1}$ Révai Nagy Lexikona III. kötet [The Great Encyclopaedia by Révai, vol. 3] (Budapest, 1911), 374.

${ }^{2}$ The academic interest in the history and historisation of security has increasingly grown recently, especially in the German-language literature: Cornel Zwierlein, 'Sicherheitsgeschichte. Ein neues Feld der Geschichtswissenschaften', Geschichte und Gesellschaft, 38 (2012), 365-86; Christopher Daase, 'Die Historisierung der Sicherheit. Anmerkungen zur historischen Sicherheitsforschung aus politikwissenschaftlicher Sicht', ibid., 387-405; Eckart Conze, 'Securitization. Gegenwartsdiagnose oder historischer Analyseansatz?', ibid., 453-67.

${ }^{3}$ Peter M. Judson, The Habsburg Empire: A New History (Cambridge, MA, 2016), 269-332. 
In the form of a real union, Hungary remained connected to Imperial Austria not only by the head of the state but certain political and financial-economic institutions, such as the joint foreign and military policies or the common market, central bank and currency. ${ }^{4}$ Despite the elites' vision, in fact, Hungary was hardly a nation-state, as the population comprised more than a dozen different nationalities, and in terms of religion, the picture was also very colourful. If we take into consideration that the compositions of religious, social and national identities were extremely diverse, Austria-Hungary can be rightfully seen as a historic playground of security-related political conflicts. Thus it constitutes a promising field for historical security research.

The main aim of our paper is to utilise this potential by investigating the security dilemmas of the local elites in two multi-ethnic regions of Transleithania: Bács-Bodrog county and especially three city municipalities in southern Hungary; and in three counties of the western Hungarian border territory (Vas, Sopron and Moson). Our main intention in the two case studies, however, is not to compare the two regions but to showcase two possible historical implementations of security studies. Therefore, we use different temporal and spatial scopes: the first case study operates at the meso level in a longue durée perspective and employs a broader notion of security, whereas the second case study looks rather at the micro level, with a limited timeframe and with one dominant security question as its focus. As for the similarities, both of us combine methods of historical discourse analysis with approaches taken from security and nationalism studies as well as regional and local history. Concerning the issues of languages and nationalism, we analyse original archival sources in order to learn the practices and attitude of the local elites and to see whether a dramatisation of security issues took place in these two regions after 1867.

Throughout the case studies, we attempt to critically apply the concept of security and the term 'securitisation' as invented and introduced to the social sciences by the so-called Copenhagen School. ${ }^{5}$

${ }^{4}$ László Péter, 'The Dualist Character of the 1867 Hungarian Settlement', in Miklós Lojkó (ed.), Hungary's Long Nineteenth Century. Constitutional and Democratic Traditions in a European Perspective, collected studies by László Péter (Leiden-Boston, 2012), 213-80.

${ }^{5}$ As the authors of the Copenhagen School point out, their speech act approach requires a distinction between three types of units involved in security analysis: 
To briefly summarise, according to the Copenhagen School "securitisation refers to the discursive construction of threat, namely a process in which an actor declares a particular issue to be an 'existential threat' to a particular referent object. If accepted as such by a relevant audience, this enables the suspension of normal politics and the use of emergency measures in responding to that perceived crisis". ${ }^{6}$ The Copenhagen authors also suggest that successful securitisation involves the articulation of a threat "only from a specific place, in an institutional voice, by elites". ${ }^{7}$ The challenge every historian faces in dealing with security studies is whether this theory, which was configured primarily for late-twentieth-century western European politics, can be applied in historical research with a totally different geographical scope. In order to answer this question, we first need to identify those historic structures that were perceived to be endangered at the time, and then to explain what role, if any, the (local) elites played in the securitisation processes. We do not make claims either that the different security issues analysed in this paper were on par with each other in terms of political or social significance, nor that they were specifically western or southern Hungarian. Our basic presumption is that as actors of security, the local elites in the late nineteenth and early-twentiethcentury Hungary often and typically declared themselves and their respective nations to be existentially threatened, and therefore to have a legitimate claim to survive the challenges of the modern times. Through the analysis of their desperate attempts to enforce this claim, we believe that we can discover local and regional aspects beyond the national features.

II

\section{CASE STUDY NO. 1: WESTERN HUNGARY}

The historic region of western Hungary has never been a unified administrative region but was composed of seven multi-ethnic municipalities: three counties (Vas/Eisenburg, Sopron/Ödenburg

(1) the referent objects; (2) the securitising actors; and (3) the functional actors. For more, see Barry Buzan, Ole Waever, and Jaap de Wilde, Security - A New Framework for Analysis (London, 1998), 33-6.

${ }^{6}$ A comprehensive summary of the securitisation theory of the Copenhagen school: Paul D. Williams (ed.), Security Studies. An Introduction (New York, 2008), 69.

${ }^{7}$ Buzan, Waever, and de Wilde, Security, 57. 
and Moson/Wieselburg) and four so-called free royal cities (Sopron/ Ödenburg, Kőszeg/Güns, Kismarton/Eisenstadt and Ruszt/Rust). According to the 1891 census, the region had altogether about 750,000 inhabitants, 340,000 of whom identified themselves as Magyars; 285,000 of whom belonged to the German-speaking community; and 100,000 of whom spoke a Slavic language (either Croatian or Slovene) as their mother tongue. In general, the closer to the border, the more multi-ethnic was the landscape. In terms of religion, the overwhelming majority was Catholic $(580,000)$, followed by a strong minority of Protestants $(125,000)$, and a significant Jewish community $(20,000)$ as well. ${ }^{8}$ The peak of the slowly changing but still super-hierarchical class-society was topped by wealthy aristocratic families such as the famous Esterházy family, which had held the hereditary office of Lord-Lieutenant of Sopron county since the early seventeenth century. ${ }^{9}$ The local public life, i.e. the county assemblies, were dominated by the Hungarian-speaking landowners. ${ }^{10}$ Since many of the important offices were filled via election at the county assembly, the gentry secured the county administration, too. Meanwhile, by far the largest social group was the peasantry, as the region's economy remained predominantly agricultural. ${ }^{11}$ By the end of the century, new social groups - bourgeoisie and industrial workers - emerged as a result of the rapid industrialisation and modernisation,

${ }^{8}$ A Magyar Korona Országaiban az 1891. év elején végrehajtott népszámlálás eredményei, I: Általános népleirás [Results of the early 1891 census in the Lands of the Hungarian Crown, Part I: General Description of the People], published by M. Kir. Központi Statisztikai Hivatal (Budapest, 1893) (hereinafter: Census 1891), 100-11.

${ }^{9}$ The family's historic attachment to Sopron county was mentioned several times at the inauguration ceremony of the new Lord-Lieutenant Prince Pál Esterházy on 27-28 Oct. 1872. See more at: Magyar Nemzeti Levéltár (hereinafter: MNL), Győr-Moson-Sopron Megye (hereinafter: GY-M-S Megye) Soproni Levéltára, Sopron Vármegye Törvényhatósági Bizottsága Közgyűlési Iratai, IV/402/b/54, no. 405.

${ }^{10}$ Their political influence was ensured by the so-called virilist system. In the Era of Dualism, half of the seats in county assemblies was reserved for the highest tax-payers. The list of the highest taxpayers in Sopron county on 10 Nov. 1871: MNL GY-M-S Megye Soproni Levéltára, Sopron Vármegye Főispánjának Iratai (1867-1871), IV/251/3, no. 118.

${ }^{11}$ According to the 1891 census, about 175,000 citizens of western Hungary declared themselves as working in agriculture. If we take into account their dependants, this makes up nearly two-third of the entire population, which corresponds with the national average (62 per cent). See more: Census 1891, 80-93. 
which brought new security challenges all over the country, including in Western Hungary.

What makes this region special is that its western border was also a state border. However, since Austria and Hungary constituted a dual monarchy, this should be considered a 'weak' border rather than a 'hard' one. The inverse of the term 'pseudo border region' could be applied to western Hungary in the Era of Dualism: it appeared not to be a border region from the external perspective but, in fact, it functioned as one. Although Vas, Sopron and Moson counties were traditionally in frequent contact with the neighbouring Austrian lands (Styria and Lower Austria) and with the imperial capital of Vienna, limited research has been carried out so far on their common border. ${ }^{12}$ After the Compromise of 1867, a precise demarcation was marked between Hungary and Austria, which caused difficulties at the local level. Since the two countries had never previously been separated by a modern, scientifically determined border, the status of some villages became a matter of dispute. Vas county, for instance, attempted to reclaim its 'historical' jurisdiction over the Styrian border villages of Sinnersdorf and Oberwaldbauern, which still belonged to Roman Catholic Diocese of Szombathely, Hungary. At the same time, four villages on the Hungarian side (Vörthegy/Wörtberg, Burgóhegy/Burgauberg, Vághegy/Hackerberg and Neudóhegy/Neudauberg) remained part of the Roman Catholic Diocese of Graz-Seckau (Austria). ${ }^{13}$

The complexity of the Austria-Hungary border and its impact on citizens is well-illustrated by the story of Ignác Feiglstock from the year 1884. Born in western Hungary, he was an optician of German origin who lived and worked in Vienna. In order to expand his business, Feiglstock was keen to be rewarded by a royal warrant, which was a prestigious title for merchants who supply goods or services to the royal court. However, Feiglstock was able to earn such honour not from the Viennese court but from the Romanian one; therefore, he needed a passport. Although he was based in Vienna, Feiglstock was

${ }^{12}$ For more on the historical antecedents, see Gergely Krisztián Horváth, Bécs vonzásában. Az agrárpiacosodás feltételrendszere Moson vármegyében a 19. század elsö felében [In the Attraction of Vienna. The Preconditions of the Agricultural Marketing in Moson County in the First Half of the 19th Century] (Budapest, 2013).

${ }^{13}$ For more, see Ferenc Pál, 'A szombathelyi püspök joghatóságának kérdései 1867 és 1914 között' [The questions of the jurisdiction of the Bishop of Szombathely between 1867 and 1914], Vasi Szemle, lxix, 3 (2015), 335-41. 
born in the nearby village of Lakompak/Lackenbach in Sopron county, so he was considered not an Austrian citizen but a Hungarian one. Thus he had to make a Hungarian passport application through the Sopron county administration that forwarded his request to the central government in Budapest. Since Romania was a foreign country, the case was also examined as a potential national security issue before the passport was authorised by the Prime Minister's Office. The bureaucratic process concluded only when the Hungarian Minister of Interior Affairs - in his letter to the head of Sopron county - referred to the king's permission for Feiglstock to use the Romanian title in the territory of Austria-Hungary. ${ }^{14}$

In order to understand the behaviour of the county elites in Hungary, one needs to be aware of the significance of the country's historical constitution and the so-called 'county question'. ${ }^{15}$ In terms of territorial administration, the country has been subdivided into counties since the Middle Ages. While the number of counties and their borders changed many times since then, they always had an important political function. From the sixteenth century onwards (when Hungary became part of the Habsburg realm), the counties served as 'bastions of the constitution' even in times when the state itself was in turmoil. However, when Hungary regained its sovereignty in 1867, the Hungarian elites were able to establish their own national parliament and government, and attempted to transform a pre-modern, multi-ethnic kingdom into a modern and unified nation-state. ${ }^{16}$ In the eyes of the nationalist-liberal elites, the statehood of Hungary was not embodied anymore on the mezzo-level of territorial administration, i.e.

14 The letter by Kálmán Tisza as Royal Hungarian Minister of Interior Affairs to Prince Pál Esterházy, Lord Lieutenant of Sopron county on 17 March 1884, MNL GY-M-S Megye Soproni Levéltára, Sopron Vármegye Főispánjának Iratai (1872-1944), IV/B/401/9, no. 86.

${ }^{15}$ For a comprehensive analysis of Hungary's constitutional development in the nineteenth century, see László Péter, 'Die Verfassungsentwicklung in Ungarn', in Helmut Rumpler und Peter Urbanitsch (eds), Die Habsburgermonarchie 1848-1918, vii, 1: Verfassung und Parlamentarismus (Wien, 2000), 239-540.

${ }^{16}$ For a more detailed summary of the attempt, see: Tamás Székely, 'A közigazgatás átalakításának programja. Modernizáció és nemzetállam-építés a dualizmus korában' [The Program for Transforming the Public Administration. Modernisation and Nationstate-building in the Era of Dualism], in Norbert Csibi and Ádám Schwarczwölder (eds), Modernizáció és nemzetállam-épités. Haza és/vagy haladás dilemmája a dualizmus kori Magyarországon (Pécs, 2018), 165-79. 
in the municipalities, but on the national level in the form of modern parliamentarism and governance. This approach necessarily led to radical reforms in public administration, so the counties once again went on the defensive concerning the centralisation and unification policies, only this time not those of the Habsburg court in Vienna, but of their own national government and parliament in Budapest. ${ }^{17}$

As a result of the reforms implemented step-by-step in the 1870s, most of them by Prime Minister Kálmán Tisza, the counties lost an increasing number of political and legal responsibilities. However, they still kept their right to nominate and elect most of the local officials, including the administrative head of the county, the Deputy-Lieutenant (alispán), and the district administrators (szolgabiró). The political leader of the county was the so-called Lord-Lieutenant (föispán) who was appointed by the king after being nominated by the Minister of Interior Affairs. During his term in office, he received instructions directly from the Prime Minister or other members of the cabinet. The LordLieutenants, who at the beginning of the era were typically members of local aristocratic families but later increasingly chosen from the ranks of distinguished public servants, had the right to command the entire county administration. The case of Prince Pál Esterházy clearly shows this strange phenomenon: the new Lord-Lieutenant of Sopron county was celebrated with such enthusiasm in October 1872 as if a minor king had been crowned in a small kingdom within a big one. However, behind the medieval and early modern facades, a new modern type of political system evolved in which the Lord-Lieutenants had to divide their loyalties between the king, county, and country, and preferably in favour of the latter. ${ }^{18}$

In this new era, however, the counties were not seen anymore as self-governing and identity-formative territorial units, but rather

17 Some counties put up heavy political resistance, not only to the centralization policies but against the entire constitutional changes of 1867. For example, in Heves county in central Hungary, the government even decided to temporarily suspend the county assembly and assigned a commissioner to administer the county; MNL Országos Levéltára (hereinafter: OL), K148, 15. d., 17 March 1869, Gróf Szapáry Gyula kormánybiztosság kinevezése Heves megyébe.

18 The inauguration of Pál Esterházy at an extraordinary county assembly on 28 Oct. 1872 was documented thoroughly in the protocol of the Sopron county assembly: MNL GY-M-S Megye Soproni Levéltára, Sopron Vármegye Törvényhatósági Bizottságának Közgyűlési Jegyzőkönyve, IV.B/402/a-m, vol. 1, no. 404. 
as integral elements of the centralised state administration, which conveyed the decisions of the government to the local levels. ${ }^{19}$ The controversial county question was one of the most embittered political debates in the dualist era Hungary, as the antagonism between the pro-county and pro-state forces escalated after the Compromise of 1867. The former were often called 'municipalists' because they were rather in favour of maintaining the historical autonomy of the counties in some sort of a modern form. In contrast, the latter were simply called 'centralists' for demanding a modern, unified, and more centralised state administration. One of the key questions was whether the county assemblies should still elect the county officials, or whether they should be nominated from above. The power and jurisdiction of the LordLieutenants was also a matter of great dispute. Deep down, the nationality question played an important role in the county question, as the government saw a potential state security issue in the multi-ethnic composition of the country and therefore advocated a more centralised state administration even at the expanse of the traditional self-governance of the counties. In the western Hungarian counties, the nobility traditionally had patriotic and pro-Habsburg feelings at the same time; therefore, they supported the 1867 policies, including the nationalisation of the territorial administration. The conflicts between state and local interests, however, often arose within the county administration itself and so far have not been analysed as matters of security.

The transformation of the country's traditional territorial administration changed the political conditions for the cities and towns as well. For an experimental period (1870-6), the government established the institution of City-Lord-Lieutenantship based on the example of the county-type Lord-Lieutenantship. This new system introduced the joint administration of certain free royal cities under the leadership of the so-called City-Lord-Lieutenant, who could not be the same person who was in charge of the county or counties in which the cities were located. The so-called 'free royal cities' held township privileges for centuries, which meant they were not part of the counties

${ }^{19}$ Several public figures of the era argued for a powerful and centralised nation state at the expanse of the 'medieval' autonomies. Read more: Béla Grünwald, Közigazgatásunk és a szabadság [Our public administration and the Liberty] (Budapest, 1876), 78; and Gusztáv Beksics, Új korszak és politikai programja [A New Era and its Political Program] (Budapest, 1889), 16-18. 
and had the right to communicate with the government directly. In western Hungary, there were four such towns with a self-governing tradition, and after the transitional period of joint administration, three of them (Kőszeg/Güns, Kismarton/Eisenstadt and Ruszt/Rust) were incorporated into their respective counties. ${ }^{20}$ Only the region's most important city, Sopron/Ödenburg could maintain some sort of level of autonomy, albeit a decreased one. As these were mostly German-speaking towns, they could be easily labelled as 'disloyal', so their enforced incorporation to the counties (in 1876) was not just a matter of administration but also a question of national security and nation-state-building. As Károly Mérey, Lord-Lieutenant of the four cities, phrased it himself in his resignation letter in 1874, he had to work under critical circumstances "in those four German-minded, unpatriotic and wrongly educated towns". ${ }^{21}$

The county authorities were responsible for maintaining public security in the countryside. It is not a coincidence that in the annual county reports public security was typically considered among the top priorities. ${ }^{22}$ Generally, in times of politically insecure or transitional periods, crime often increases; in Hungary, it was the late 1860s when the new authorities had to face the last wave of the so-called betyár crisis. In the nineteenth century, the betyárs, who were armed criminals, were hiding across the Great Plain or in the hills and woods of Hungary. They carried out a series of criminal activities, including banditry, murder, highway robbery, horse theft, train robbery, etc. Although many of them have become legendary Robin Hood-like figures in Hungarian folklore, in fact, they posed a real danger to public safety. ${ }^{23}$ When these bandits also appeared in western Hungary, the Lord-Lieutenant of Vas County was appointed 'royal commissioner' and was granted

${ }^{20}$ For example, the case of Kismarton/Eisenstadt: Landesarchiv Burgenland, Archiv der Freistadt Eisenstadt, M/II: Ratsprotokoll und Generalversammlungsprotokollbücher 1871-1884: "Kismarton szabad király város közönségének 1876. évi július 4-én tartott ülésének jegyzőkönyve”.

${ }^{21}$ Lord-Lieutant Károly Mérey's resignation letter to Vilmos Tóth, Minister of Interior Affairs on 24 Jan. 1874: MNL OL, K148, 83. d, 1867. III, 19-20.

${ }^{22}$ Annual county report (1875) from Sopron county by Vice-Lieutenant István Ferency on 24 April 1876: MNL GY-M-S Megye Soproni Levéltára, Sopron Vármegye Főispánjának Iratai (1872-1944), IV/B/401/2, no. 158.

${ }^{23}$ For more, see Shingo Minamizuka, A Social Bandit in Nineteenth Century Hungary: Rózsa Sándor (Boulder, CO, 2008). 
extraordinary rights and law enforcement capabilities to fight against them and restore order. ${ }^{24}$ Similarly to the betyárs, the Roma community was also considered by the local elites as a security threat. In the nineteenth century, they were not yet settled down in Hungary but rather migrating across the country. Most of them remained hopelessly disintegrated and excluded from society. ${ }^{25}$ However, it is very difficult to examine the history of the Roma community because the contemporary sources rarely mention them, and even if they do, they do so only in connection with criminal activities such as illegal border crossing, robberies, theft, or even beggary. This approach by the local authorities to the Roma people strengthened the preconceptions of the society, labelling the Roma people in general as a security issue. As the protocol of the Vas County Assembly in 1870 put it, the most effective way to discipline the 'gipsies' was to make them starve in prison. Otherwise, they argued, "the wandering of this race living under shanties in the woods distant from settlements can be hardly prevented because they do not like to work, so they do not go out charring, they rather got used to beggaring and slick thieving and they are not even afraid of imprisonment because then they have a roof over their heads and a meal on their plate". ${ }^{26}$

Since the gendarmerie was not established until 1881, and there was no police outside of the capital either, the county authorities had to practice traditional police work, including gathering intelligence or monitoring suspicious elements. ${ }^{27}$ The Lord-Lieutenants were expected

${ }^{24}$ Public security regulations issued by József Széll, Lord-Lieutenant and Royal Comissioner of Vas County, on 18 Nov. 1868, MNL Vas Megyei Levéltára, Vas Vármegye Főispáni Elnöki Iratok 1868 (Királybiztosi iratok), IV/302/3, 5045/8.

${ }^{25}$ István Kemény, 'History of Roma in Hungary', in István Kemény (ed.), Roma in Hungary (Bradenton, FL, 2006), 23-42.

${ }^{26}$ Protocol of the county assembly of Vas county on 6 May 1870, MNL Vas Megyei Levéltára, Vasvármegye Bizottmányi Gyűléseinek Jegyzőkönyve 1870 Január-December, IV/303, no. 2016/870, 300-1.

${ }^{27}$ According to the historian Imre Ress, the intelligence gathering and surveillance activities of the dualist-era Hungarian state police were inspired first and foremost by the government's ethnic minority policies. See Imre Ress, 'A kormányzati hírszolgálat átalakulása az Osztrák-Magyar Monarchiában a kiegyezés után 1867-1875' [The Transformation of the Governmental Intelligence in the Austro-Hungarian Monarchy after the Compromise 1867-1875], in Ferenc Csóka (ed.), Szakszolgálat Magyarországon: avagy tanulmányok a hírszerzés és titkos adatgyüjtés világából (1785-2011) (Budapest, 2012), 93-124. 
to report any activity on the territory of their respective counties that could be considered dangerous to the nation-state. ${ }^{28}$ In their strange ways, the county authorities occasionally engaged in the surveillance of ordinary citizens, and if they found dangerous figures, spying on them could even become part of the every-day administration. Those who were found to be problematic - especially local actors of the political opposition, religious groups and national minorities - could have been securitised as potential traitors of the liberal and national state order established in 1867. One example illustrating this is the case of the Catholic People's Party. Classical liberal social policies accompanied the Hungarian elites' nationalist state-building paradigm; consequently one of the main wishes of the governing liberal party was to introduce civil marriage in Hungary in order to separate the state from the Catholic Church. The so-called religious policy laws were adopted by the parliament in the 1890s, causing public outrage in Catholic circles, especially in the countryside, including in western Hungary. ${ }^{29}$ The nationwide debate led to the establishment of a new political party: the Catholic People's Party. As a result of the debate over the religious policy laws, the county authorities put the politicallyactive Catholics under surveillance, including members of the clergy, securitising them as 'traditionalists' who endangered the vision of the liberal nation-state. At the same time, the liberal elites were accused by the proponents of the Catholic movement of "extremist secularisation and modernisation". ${ }^{30}$

Another important debate which took place after 1867 was the issue of anti-Semitism and securitisation of the Jewish community, which escalated mostly in the late 1870s and the 1880s. According

${ }^{28}$ Letter by Dezső Perczel, the Minister of Interior Affairs, to the Ede Reiszig, Lord-Lieutenant of Vas county, on 8 Dec. 1896: "all political matters of public interests, nationality and agrarian-socialist movements that need to be addressed by the government, should be reported without delay", MNL Vas Megyei Levéltára, Vas Vármegye Főispáni Elnöki Iratok, IV/401/a/1, res. 75.

${ }^{29}$ For more on the history of the Catholic Church and the Catholic People's Party in dualist-era Hungary, see Tibor Kleistenitz, 'Modern katolicizmus? Vallási megújulás és politikai törekvések a dualizmus korában' [Modern Catholicism? Religious Revival and Political Aspirations in the Era of Dualism], in Csibi and Schwarczwölder (eds), Modernizáció és nemzetállam-épités, 263-81.

${ }^{30}$ Political leaflet by the Catholic People's Association (Katholikus Népszövetség) on 5 May 1910, MNL Vas Megyei Levéltára, Vas Vármegye Főispáni Elnöki Iratok 1908-1911, IV/401/a/5, 1910, res. 20. 
to then-contemporary public opinion, the Hungarian society was witnessing mass immigration of Jews, mostly from Galicia and from the Russian Empire. ${ }^{31}$ After 1867 the liberal governments openly promoted and legalised the emancipation of Jews in the hope of boosting modernisation across the country. However, the reception and assimilation of the newcomers was a complicated and slow process, full of social conflicts. After the so-called Tiszaeszlár affair - wherein Jews were falsely accused of ritually murdering a Hungarian girl Eszter Solymosi - grew into a nationwide scandal, it was just matter of time until a group of extremists led by Győző Istóczy from Vas county established a new, openly anti-Jewish political party in $1883 .{ }^{32}$ Although the so-called Anti-Semitic Party ceased to exist after a few years, the securitisation attempts with respect to the Jewish community remained high on the agenda in public life throughout the whole era. In western Hungary, it was mostly in Moson county and the city of Sopron/Ödenburg where the tensions surrounding the issue of alleged Jewish immigration escalated. For example, on 1 November 1882 in the village of Nyulas/Jois in Moson County, angered locals broke into the house of Jewish tradesman Móricz Steiner. They not only robbed and damaged his home but shot his wife to death, who was trying to escape from a lynch law. ${ }^{33}$ Similar anti-Semitic rioting took place in other nearby villages as well. Therefore the Lord-Lieutenant of Moson County was appointed royal commissioner to restore public safety with military assistance. According to the report filed by Lord-Lieutenant baron Imre Miske to Prime Minister Kálmán Tisza, the locals attacked the Jews because they blamed them for their poverty and misery. ${ }^{34}$ Meanwhile, in the city of Sopron reports claimed that not only common

${ }^{31}$ Recent research rejects the then-contemporary myth of Jewish mass immigration in the Era of Dualism, claiming that the phenomena was already concluded by the 1860s. For more see Miklós Konrád, 'A galíciai zsidó bevándorlás mítosza' [The Myth of the Jewish Immigration from Galicia], Századok, clii, 1 (2018), 31-60.

${ }^{32}$ For more on the history of the Jewish community and the Anti-Semitic Party in dualist-era Hungary, see János Gyurgyák, A zsidókérdés Magyarországon [The Jewish Question in Hungary] (Budapest, 2001), 61-87 and 314-39.

${ }_{33}$ Prime Minister and Minister of Interior Affairs Kálmán Tisza's telegram to Baron Imre Miske, Lord-Lieutenant of Moson county on 4 Nov. 1882, MNL GY-M-S Megye Győri Levéltára, Mosonmagyaróvári Fióklevéltára, Moson Vármegye Főispánjának Iratai (1872-1923), IV/B/901/b, no. 171.

${ }^{34}$ Report by baron Imre Miske, Lord-Lieutenant and royal commissioner of Moson county to Prime Minister and Minister of Interior Affairs Kálmán Tisza on 
people demonstrated an anti-Semitic attitude, but more and more intellectuals such as clergymen and school teachers as well. However, Lord-Lieutenant prince Pál Esterházy warned the government not to make the mistake of generalisation. ${ }^{35}$

Local elites also played an important role all over Hungary in times of national elections. Unlike in other countries in contemporary Europe, the Hungarian political life - at least in the late nineteenth century - was not fragmented by mainstream ideologies (conservatism vs liberalism) but by the political approach towards Austria and the Habsburg dynasty. The ruling parties promoted the system of 1867 as a reasonably good basis for promoting national interests, whereas the main opposition forces demanded greater independence from Vienna. In western Hungary, the voters typically elected pro- 1867 candidates and this tradition was first questioned only in the 1890s when the Catholic People's Party gained momentum in this countryside region as well. In the early twentieth century, the Independence Party also broke through in western Hungary because of the nationwide discontent with the ruling liberals. In any case, despite some serious deficiencies, the country had a functioning parliamentary system with regular elections, although only 6-8 per cent of the population enjoyed voting rights. The MPs were elected in individual electoral districts within the counties and cities, and the local election campaigns were infamous for violence and corruption on both sides. ${ }^{36}$ Furthermore, the ruling party benefited from the unfair advantage of using the public administration as a source of information and as a tool for exerting pressure. As József Ernuszt, Lord-Lieutenant of Vas County told the district administrators of his municipality during the critical 1905 election campaign, the right of free speech and gathering are core constitutional rights of all citizens; therefore, the "heavy agitation by the united opposition cannot be prohibited unless it goes beyond the

11 Nov. 1882, MNL GY-M-S Megye Győri Levéltára, Mosonmagyaróvári Fióklevéltára, Moson Vármegye Főispánjának Iratai (1872-1923), IV/B/901/b, no. 177.

${ }^{35}$ Reports by prince Pál Esterházy, Lord-Lieutenant of Sopron county to Prime Minister Kálmán Tisza, MNL GY-M-S Megye Soproni Levéltára, Sopron Vármegye Főispánjának Iratai (1872-1944), IV/B/401/9, no. 205 (8 Sept. 1883) and no. 228 (7 Oct. 1883).

${ }^{36}$ For more, see József Pap, Parliamentary Representatives and Parliamentary Representation in Hungary (1848-1918) (Frankfurt am Main, 2017); and András Gerő, The Hungarian Parliament (1867-1918). A Mirage of Power (New York, 1997). 
law". In cases where this allegedly happened, which was, of course, a grey zone of legal interpretation, the district administrators were expected to intervene 'wisely but forcefully', otherwise they were held responsible for the deterioration of public safety. They also had to report every important moment of the election day via telegram to the Lord-Lieutenant, who in cases of national significance immediately forwarded the information to the government. ${ }^{37}$ In the dualist era, it was not rare that the supporters of the different parties clashed on the streets during election campaigns and the county administration had to request police or military assistance in order to restore the peace. However, it was quite unusual even among the most experienced contemporaries, that the candidates themselves performed violent acts. This was the case in January 1905, when Hugó Laehne, the opposition candidate of the Kőszeg/Güns constituency in Vas County, was accused of threatening the pro-government voters with his revolver. ${ }^{38}$ Despite the scandal, he managed to win the seat in the parliament, which for the first time in the history of the dualist system was formed by a majority of opposition forces. This caused not only a serious political crisis but also became a persistent headache for the king himself.

Finally, yet importantly, it is necessary to mention the nationality question, upon which much more focus is placed in the second case study. According to the nationality law of 1868 (based on the concept by recognised liberal statesmen József Eötvös and Ferenc Deák drafted by the latter in the Hungarian Parliament), the society of Hungary was composed of several different nationalities, and regardless of their ethnolinguistic identity all of the citizens enjoyed equal rights and together formed one single political nation: Hungary. ${ }^{39}$

${ }^{37}$ Instructions by József Ernuszt, Lord-Lieutenant of Vas County to the district administrators of Vas County on 12 Jan. 1905 MNL Vas Megyei Levéltára, Vas Vármegye Főispáni Elnöki Iratok 1904-1907, IV/401/a/4, 1905, no. 6.

38 Tamás Székely, “"A revolveres képviselő” - A kőszegi 1905-ös képviselőválasztás története' ["MP with a revolver" - A history of the 1905 elections in Kőszeg], in Vas Megyei Helyismereti és Helytörténeti Közlemények, ii (Szombathely, 2009), 46-61.

${ }^{39}$ More about the parliamentary debate and the 1868 nationality law: Gábor G. Kemény (ed.), Iratok a nemzetiségi kérdés történetéhez a dualizmus korában, i: 1867-1892 [Documents about the History of the Nationality Question in the Era of Dualism, i: 1867-1892] (Budapest, 1952), 129-67; István Schlett, A nemzetiségi törvény javaslat országgyúlési vitája 1868 [The Parliamentary Debate of the Proposal of the Nationality Law 1868] (Budapest, 2002). See also László Péter, 'Law of XLIV of 1868. On 
In fact, however, the representatives of the ethnic minorities never accepted this controversial vision of the Hungarian elites and desperately resisted the government's so-called 'Magyarization' efforts. In the first decades of the Dualist era, these efforts took place mostly in the form of education and language policies, which did not really meet with heavy resistance in the multi-ethnic region of Western Hungary. ${ }^{40}$ These phenomena can be explained through the concept of national indifference which claims that the nationalist struggle in the Habsburg-ruled countries was not driven by a mass movement for the nation, but rather the opposite - by the indifference, ambivalence, and opportunism of 'ordinary people' when dealing with issues of nationhood and with claims made by nationalists. ${ }^{41}$ American sociologist Rogers Brubaker, a pioneer of the concept, argues that national identities are not the logical outcome of an already existing ethnic identity, nor is the nation a real group, but it appears rather as a practical category in an institutionalised form based on a contingent event. ${ }^{42}$ The proponents of 'national indifference' insist there was no mass breakthrough of nationalism in the Habsburg lands before the First World War, but that it was the general breakdown of society because of the war that created the conditions for the 'massification' of national movements. ${ }^{43}$

Indeed, the nationality question in western Hungary escalated only after the Great War. However, from the side of the elites, the ethnic minorities were often securitised years before as obstructive elements of the political nation. In Vas, Sopron and Moson counties, where the border area was inhabited mostly by German-speakers, the Hungarian authorities saw a potential national security risk in 'Great German

the Equality of Nationality Rights" and the Language of Local Administration', in Hungary's Long Nineteenth Century, 343-54.

${ }^{40}$ For more on the national differentiation process in certain areas of Western Hungary, see Gerhard Baumgartner, 'Die National Differenzierungsprozess in den ländlichen Gemeinden des südlichen Burgenlandes', in Andreas Moritsch (ed.), Vom Ethnos zu Nationalität. Der nationale Differenzierungsprozess am Beispiel ausgewählter Orte in Kärnten und Burgenland (Wien-München, 1991), 93-155.

${ }^{41}$ Marteen Van Ginderachteer and Jon Fox (eds), National Indifference and History of Nationalism in Modern Europe (London-New York, 2019).

${ }^{42}$ Rogers Brubaker, Nationalism Reframed. Nationhood and the National Question in the New Europe (Cambridge, 1996), 13-22.

43 Tara Zahra, 'Imagined Noncommunities: National Indifference as a Category of Analysis', Slavic Review, lxix, 1 (Spring, 2010), 93-119. 
nationalism', especially at the turn of the twentieth century. ${ }^{44}$ Their fears were not entirely unfounded. The famous proposal for 'United States of Greater Austria', propagated in a book written by Archduke Franz Ferdinand's right-hand man, the ethnic Romanian lawyer Aurel Popovici back in 1906, would have meant a Trianon-like disintegration of the Lands of the Holy Crown. ${ }^{45}$ Historians have widely discussed Popovici's book but paid little attention to the fact that it was the first proposal that would have granted large parts of western Hungary, together with the city of Pozsony/Pressburg, to German-Austria, one of the fifteen different federal states of Greater-Austria. Two years later Josef Patry, a Bohemia-born journalist of German origin, published a political leaflet entitled Westungarn zu Deutschösterreich (Western Hungary to Austria), which triggered widespread outrage in Hungary. ${ }^{46}$ The analysis of this question, however, would lead us to another chapter in the history of the region, namely the post-war border conflict between Austria and Hungary over the disputed territory that later has become known as Burgenland. ${ }^{47}$

III

CASE STUDY NO. 2: SOUTHERN HUNGARY PREDETERMINED POWER SHARING OF NATIONS/NATIONALITIES IN MUNICIPALITIES

The southern part of Hungary consisted of several different political and administrative regions from the time of the Ottoman conquest until the twentieth century. Following the Great Turkish War, the borders of Hungary again reached the Danube-Sava line, but the territory was divided, even after the centralising tendencies following the Compromise

${ }^{44}$ Letter from the Ministry of Interior Affairs to István Békássy, the Lord-Lieutenant of Vas County, on 29 March 1914, MNL Vas Megyei Levéltára, Főispáni Elnöki Iratok 1914, IV.401/a/7, res 51.

${ }^{45}$ Aurel Popovici, Die Vereinigten Staaten von Groß-Österreich. Politische Studien zur Lösung der nationalen Fragen und staatrechtlichen Krisen in Österreich-Ungarn (Leipzig, 1906).

${ }^{46}$ In 1918, when the author's vision became a distinct possibility, he republished his thoughts as a book: Josef Patry, Westungarn zu Deutschösterreich (Wien, 2018).

${ }^{47}$ Mari Vares, The Question of Western Hungary/Burgenland 1918-1923, doctoral dissertation, University of Jyväskylä, 2008. 
of 1867. Most of the region was reorganised in the eighteenth century as counties of the Kingdom of Hungary, forming the county municipalities of Bács-Bodrog between the Danube and Tisza rivers, and Torontál and Temes to the east of the Tisza. The Military Border area (Militärgrenze or Katonai Határörvidék) was established, stretching along the Hungarian-Serbian border. ${ }^{48}$ Unlike the municipalities, the Military Border fell outside of the authority of the Hungarian National Assembly, with the central imperial government in Vienna exercising direct control over the area until its reincorporation into the Hungarian county-system in 1872-3. Moreover, the southern bank of the Drava River formed part of Croatia-Slavonia, an autonomous political unit ${ }^{49}$ of the Kingdom of Hungary. Southern Hungary was more diverse ethnically than other parts of the Kingdom, with none of the Hungarian, German, Serb, Bunjevci ${ }^{50}$ or Romanian nationalities constituting an absolute majority.

Unlike the western Hungarian counties, Bács-Bodrog was not adjacent to a state border, but it included the southern border of the Hungarian-populated area with various German enclaves, making it in this sense a border region. Furthermore, the Hungarian-Serbian (Hungarian-Croatian) language border was close to the Kingdom of Serbia, the centre of the 'Pan-Serbian' cultural and political aspirations that reached over state borders.

${ }^{48}$ The Principality of Serbia, an autonomous province under the Sultan's sovereignty until its complete independence in 1878 .

${ }^{49}$ Since the Middle Ages Croatia retained some segments of its statehood even after the Hungarian-Croatian Compromise of 1868 (Nagodba), including a separate National Assembly (Sabor) and executive powers, although its inhabitants were Hungarian citizens and common legislative affairs were subject to the Hungarian National Assembly, which included representatives of the Zagreb Sabor. For more, see Jasna Turkalj and Damir Karbić (eds), A horvát-magyar együttélés történelmi öröksége A horvát-magyar együttélés fordulópontjai - Prekretnice u suživotu Hrvata i Mađara [The turning point of the Croatian-Hungarian cohabitation], MTA Történettudományi Intézet - Horvát Történettudományi Intézet (Budapest, 2015).

${ }^{50}$ A South Slavic ethnic minority, speaking the dialect of the Croatian language with Ikavian pronunciation and practicing the Roman Catholic confession, which strongly separated them from the Orthodox Serbs. The censuses did not include Bunjevci, as they spoke Serbo-Croatian, which before the twentieth century was considered as one single language. The Serbian Cyrillic script also separated the Serbs from other Serbian/Croatian-speaking communities in the region, using the Latin alphabet. 
Table 1. Languages declared in Bács-Bodrog county ${ }^{51}$

\begin{tabular}{lll}
\hline \multicolumn{1}{c}{ Mother tongue } & $\mathbf{1 8 8 1}$ & $\mathbf{1 8 9 1}$ \\
\hline Hungarian & $36.7 \%$ & $40.3 \%$ \\
\hline German & $25.5 \%$ & $26.8 \%$ \\
\hline Serbo-Croatian & $27.8 \%$ & $27.6 \%$ \\
\hline Number of inhabitants & 638,063 & 716,488 \\
\hline
\end{tabular}

The significance of the county administration and the strong presence and leadership of the Hungarian nobility in the county assembly $^{52}$ and council ${ }^{53}$ is similar to western Hungary, but the territory was also the homeland of a strong Serb urban elite, especially in

${ }^{51}$ A Magyar Korona Országaiban az 1881. év elején végrehajtott népszámlálás fóbb eredményei megyék és községek szerint részletezve [The main results of the 1881 census of the Lands of the Holy Crown detailed by counties and communities], published by Magyar Királyi Országos Statistikai Hivatal (Budapest, 1882); https://library. hungaricana.hu/hu/view/NEDA_1881_02/?pg =0\&layout=s [Accessed: 30 June 2019] (hereinafter: Census 1881), 29; Census 1891, 100-03, 106-09. The native language was registered from the 1881 census, but the category of nationality was not considered in Hungarian censuses in the century.

${ }^{52}$ The main organ, the 'small parliament' of the municipality, representing the county or city as a whole, embodied by elected representatives of the county nobles and communes for the county - and citizens with relatively high property census for the city assemblies until the Municipality Act's entry into force on 1 Jan. 1872. E.g. the petitioners of the undermentioned Versec wrote in the name of 1194 Serb voters (1867) in a city of 8630 Orthodox residents (1870), which in that case meant 13.8 per cent of the people had the right to vote. A Magyar Korona Országaiban az 1870. év elején végrehajtott népszámlálás eredményei a hasznos háziállatok kimutatásával együtt [The 1871 census of the Lands of the Holy Crown with accounts on the domestic livestock], published by Országos Magyar Királyi Statistikai Hivatal (Pest, 1871); https://library.hungaricana.hu/hu/view/NEDA_1870/?pg $=135 \&$ layout $=$ s [Accessed: 29 June 2019] (hereinafter: Census 1870), 60; letter from 1194 voters of Versec to the Interior Minister, 7 July, 1867, MNL K148 Bm. elnöki iratok, III.65-2154). The assembly's most significant rights were to draft statutes for the municipality, elect its council and discuss state matters.

${ }^{53}$ Or municipal board, the quasi 'municipal government' dealing with everyday matters of the county or city, consisting of officials elected, supervised and paid by the assembly. Its president, the Deputy-Lieutenant (counties) or Mayor (municipal cities) had the right for a single suspensive veto from 1872 against government regulations - which thus could be 'thrown back' to the government for further consideration, but after a second promulgation, the Deputy-Lieutenant/Mayor was obliged to execute it. 
two of the three free royal cities of Bács-Bodrog: Zombor (both in Serbian and German: Sombor), and Újvidék (in Serbian: Novi Sad, in German: Neusatz). ${ }^{54}$ The latter served as the cultural centre of all Serbs, hosting the only Serb lyceum in Hungary and industrial and cultural associations, such as the Matica Srpska and its newspaper (Zastava), thus gaining the nickname: the 'Serb Athens'. The Serb elite, initially backed by its independent Orthodox Church (Patriarchate of Karlovci) was responsive to Serb nation-building, having since 1848 the strongest and most organised national movement in the Kingdom of Hungary, unlike the German minority, which was loyal to the Hungarian political nation with its German language and culture (along with the Bunjevci of Zombor). Therefore the nationality question had vastly different dimensions here than in western Hungary.

This case study focuses on three different municipalities of the region: the free royal cities of Zombor, Újvidék and Versec (in Serbian: Vršac, in German: Werschetz, in Romanian: Vârșet) - the former two exempted from Bács-Bodrog, and the latter from Temes county as autonomous municipalities. These free royal cities present great examples of how the German, Hungarian, Bunjevci and Serb ethnic and/or national groups struggled for local leadership after a century of peaceful cohabitation, which included the establishment of a stable, proportionally divided system of local political governance in the eighteenth and nineteenth centuries by distributing offices of the municipal council, based on (originally) religious identity. This equilibrium was challenged by the modern 1848 constitution, ${ }^{55}$ and especially its executive orders in $1867,{ }^{56}$ which declared the legal

${ }^{54}$ The new Municipality Act limited municipal autonomy, representing the tendency of the growing power of the Lord-Lieutenant thus securing the influence of the central administration along with the autonomy.

${ }^{55}$ This Constitution consisted of several Acts (known as the 'April Acts'), passed by the 1847-8 legislature, suspended after the War of Independence of 1848-9 and put into force again in February 1867 as the first step of the Compromise. Note that the Kingdom of Hungary never had a charter constitution; the historical constitution consisted of dozens of written and unwritten regulations, such as Acts and customary law, with the local consuetudo or usus holding great significance, especially in the municipalities.

${ }^{56}$ Governmental regulation regarding the municipalities (10 April 1867). Magyarországi törvények és rendeltek tára 1867 [Collection of the acts and regulations of Hungary 1867] (Pest, 1868), 89; https://library.hungaricana.hu/hu/view/ OGYK_RT_1867/?pg=0\&layout=s [Accessed: 29 June 2019]. 
equality of the citizens and forbade the customary use of censuses for dividing up the election of municipal officials based on nationality and religion. The elites, parties of each of the free royal cities mentioned above, tried to maintain or recover their positions in different ways against their rivals, each of them appealing to the newly-formed responsible Hungarian government, which had to find a solution between the forces of nationalism and ethnicity in order to preserve peace and consolidate the region after the regime change of 1867. Hence what follows is an examination of the power struggles which took place in the three respective municipalities after the Compromise of 1867.

According to the 1881 census, the city of Zombor had 24,693 inhabitants, and 65.8 per cent of the population spoke Serbian, 20.5 per cent Hungarian, and 10.8 per cent German as their mother tongue, while the religious affiliation was 42.8 per cent Orthodox and 52.5 per cent Roman Catholic; thus neither of the two almost equal religious communities could gain a qualified majority. ${ }^{57}$ The discrepancy between the Orthodox (52.5 per cent) and Serb (65.8 per cent) population shows that the city had a significant Catholic Bunjevci minority, speaking a dialect of Serbo-Croatian and with an identity aligned with the Hungarian political nation. Upon becoming a self-governing municipality in 1749 , the assembly of the city promptly drafted a statute establishing a rotational system, hence electing a Catholic citizen for mayor, an Orthodox for the position of the city magistrate (fóbiró) and so forth, maintaining parity in the city offices and swapping them between the two religious groups in every election. 'The Alternative' - as the locals called this rotational system of the council - was maintained despite the efforts of the central administration of the state to prohibit it and was not suspended until the city came under the jurisdiction of the Serbian Voivodship and Banat of Temes. ${ }^{58}$ During the era of

${ }^{57}$ Census 1881, 29; Census 1891, 100-03, 106-09. The Jewish population, totally between 2,5 per cent and 5 per cent of the residents of the examined municipalities was not subject to the political rotation system of the religious-national parties in the municipalities, lacking suffrage until the Act XVII of 1867 (Jewish Emancipation Act).

${ }^{58}$ Petition from the Roman Catholics of Zombor to the Royal Hungarian Lieutenancy. Historical Archives of Sombor, Magistrat Sl. I Kr. Grada Sombora Skupštinsko odeljenje 1852-67, 123. The Serbian Voivodship and Banat of Temes was established by the emperor following the request of the Serb National Congress of 
neo-absolutism (1849-60), offices were appointed by the central state administration; therefore, a fair election could not prevail. The Catholic Hungarians and Germans constituted less than a third of the residents, but the Serbian-speaking locals were not a homogenous community due to the Bunjevci, who declared only their language and culture as held in common with the Serbs, and were otherwise aligned with the Catholics, announcing their loyalty to the Hungarian political nation and their 'hatred' towards the recently ceased Serbian Voivodship - expressing their feelings of insecurity. ${ }^{59}$

The Alternative - following its retention with the help of a successful petition from the Catholics of Zombor before the 1861 municipal elections ${ }^{60}$ - faced a major obstacle because of the above-mentioned Governmental Regulation of 1867 on the municipalities, issued as a preparation for the next local elections. Given this state of affairs, the Catholic members of the city assembly regarded the Alternative as a bilateral agreement, unilaterally unmodifiable; while the Orthodox wanted to end the old system, referring to the governmental regulation which forbade any discrimination for municipal officials based on nationality and religion. Had the assembly kept the Alternative, a Catholic mayor would have been elected. ${ }^{61}$

1848, becoming a German-speaking administrative unit, crownland of the temporarily centralised Habsburg Empire until its reincorporation to the Hungarian counties in 1860-1. For more, see Die Habsburgermonarchie 1848-1918, iii: Die Völker des Reiches (2003).

${ }^{59}$ A notable example of the political activism of the Bunjevci minority is their 1861 petition to the Royal Hungarian Lieutenancy, where they considered themselves as "'Roman Catholic Dalmatians', 'Slavic people of Dalmatian and Serbian dialect', who were immovably faithful to the Hungarian Homeland", Historical Archives of Sombor, Magistrat Sl. I Kr. Grada Sombora Skupstinsko odeljenje 1852-67, 123.

${ }^{60}$ Helytartótanács 47485 intézvénye, Helytartótanács 56980 intézvénye. Cited by: Ágnes Deák: “"Mindenkor mindent nemzetiség kérdésévé tesznek”: Helyhatósági választások etnikai, felekezeti és nemzetiségi választó vonalak erőterében (1867)' ["They always make everything a matter of nationality": Municipal elections in the fields of ethnical, religious and nationality lines, 1867], in Zita Horváth and János Rada (eds), Társadalomtörténeti Tanulmányok Tóth Zoltán emlékére (Miskolc, 2017) (hereinafter: Deák 2017), 273-93, 279-80. I used this study as a basis and I integrated further archival sources.

${ }^{61}$ Letter from the Govt. Commissioner to the Minister of Interior (23 May 1867), MNL K148 Bm. elnöki iratok III.65-2154. 
The turmoil grew after some misconduct during the registration of voters: after several complaints, the minister of the interior decided to send the Lord-Lieutenant of Bács-Bodrog, the Serb Miklós Mihajlovits, as a royal governmental commissioner with the mandate to conduct the council elections, maintain order, and pacify the 'exaggerated national fights'. The minister commended the commissioner to suspend the elections if no "peaceful concurrence between the nationalities" was attained. ${ }^{62}$ It was self-evident that the Alternative, in spite of originally naming religious groups as holders of special, collective political rights, had turned into a political division of nations/nationalities, thus changing the 'frame' of security actors. How ethnic and religious groups identified themselves as members of a cultural or political nation is a good example of the complexity of the boundaries between the ethnical and religious groups and nationalities in this region.

The commissioner declared that the Alternative was outworn and that it did not fit the 'constitutional times'; was disadvantageous for establishing professional administrative staff; and most importantly that it collided with the Act XXIII of 1848 (Act on the Free Royal Cities), executed by a Governmental Regulation in 1867, which had granted the assembly the right to appoint and elect city officials autonomously, regardless of religion and nationality. Nonetheless, the commissioner suggested to keep the Alternative for political reasons, on the one hand, because the Serbs held an absolute majority in the leading bodies since the pre-1867, unconstitutional era, making SerboCroatian with Latin script (thus the written language of the non-Serb South Slavs in the area, also probably understood by most of the Serbs) the administrative language, and on the other, the Hungarians, Germans and hitherto so-called Bunjevci, who identified themselves as Hungarians, were worried about Serb 'oppression'. Thus that the main goal should be to pacify the municipality and reach common compliance. ${ }^{63}$ Despite the lack of consent from the Serb assembly representatives, the assembly and the temporary mayor agreed to set aside the Alternative and stick to the laws, which led to further

${ }^{62}$ Letter from the Minister of the Interior to the municipality of Zombor (24 April 1867), MNL K148 Bm. elnöki iratok III.65-1970; letter from the Minister of the Interior to Lord-Lieutenant Mihailovits (24 April 1867), MNL K148 Bm. elnöki iratok III.65-1970.

${ }^{63}$ Letter from the Govt. Commissioner to the Minister of Interior (23 May 1867), MNL K148 BMm.elnöki iratok III.65-2154. 
complaints from the Catholic community. The minister, in his final judgement, ordered the commissioner and the president of the election to respect the freedom of the appointing board, but to try to 'affect the board with influence' and keep an eye on the consensus of the assembly. The main goal was to reach and maintain 'peace, fraternity and concord' among the nationalities. Therefore the minister showed a willingness to accept that bilingual protocols in both the state language and the official language of the municipality - in this case, Hungarian and Serbian respectively - be sent from the municipality to the government. ${ }^{64}$

Although municipalities were conveyors of the executive power, i.e. the state government, they still retained the right of self-governance..$^{65}$ The struggle between the central government and the free royal city of Zombor started once again in 1868 when the minister appointed another government commissioner. This time the sole purpose was an investigation regarding the assassination of the monarch of Serbia, during which the commissioner arrested residents of the city municipality without the minister's authorisation. The minister respected Zombor's complaint on the matter and ordered his commissioner not to violate municipal autonomy. ${ }^{66}$

The so-called 'municipalist-centralist' struggle between the government and municipalities conjoined with local nationalistic conflicts in Újvidék between the Roman Catholics and the Serb city politicians. The Serbs wanted to keep their positions gained under the Voivodship. The 1867-8 conflict in Újvidék was also part of a wider phenomenon - it was more about the emerging Serb political movement than a matter of local interest.

${ }^{64} \mathrm{Ibid}$.; letter from the Interior Minister to János Vuits, president of the electoral board (29 May 1867), MNL K148 Bm. elnöki iratok III.65-1970. Letter from the Interior Minister to the govt. commissioner (29 May 1867), MNL K148 BM elnöki iratok III.65-2154.

${ }^{65}$ Máté Pétervári, 'One Empire and Two Ways of Public Administration: The Second Level Administrative Division in Austria-Hungary', Journal on European History of Law, 9 (2018), 133-40, 135.

${ }^{66}$ Letter from the Zombor assembly to the Interior Minister (13 Aug. 1868), MNL K148 Bm. elnöki iratok III.1505; letter from govt. commissioner to the Interior Minister (14 Aug. 1868), MNL K148 Bm. elnöki iratok III.1505; letter from the Interior Minister to the govt. commissioner (3 Sept. 1868), MNL K148 Bm. elnöki iratok III.1505; letter from the Interior Minister to the Zombor assembly (3 Sept. 1868), MNL K148 Bm. elnöki iratok III.1505. 
Right after becoming a free royal city, Újvidék established a similar system of power-sharing as in Zombor, with parity among the municipal council members between the Catholics and the Orthodox. In Újvidék, a city of 19,119 people, the Orthodox Serbs (the two categories indicated the same group of residents) composed a comparatively stronger, though still a relative minority by constituting 42 per cent of the population, with 36 per cent Catholics and 16 per cent Protestants according to the 1870 census. ${ }^{67}$ The wealthy Serb city elite was stronger than in other municipalities due to its network of cultural and industrial associations, along with the daily newspaper Zastava. Unfortunately, we do not have an account regarding the division along religious, language, or nationality lines of the voters, neither of the members of the assembly or the council..$^{68}$ As the first language census showed, the Hungarian and German population made up half of the city (in equal proportion), a minority of them with a Protestant confession. ${ }^{69}$

Despite the Serb majority in the municipal assembly, the Catholic party was able to maintain the parity in the 1861 elections and wanted to carry on the custom at the next 'free ${ }^{70}$ elections as well. ${ }^{71}$ The 1867 non-Serb petitioners called themselves 'Hungarian patriots' and blamed the Serbs for abandoning the system of parity. The Interior Minister informed the president of the electoral board about the complains and urged enforcement of the 'fraternal nationality concord' through a 'joint agreement' of the assembly; should it fail, the legal regulations would be applied - which would ultimately have meant a council election without prior diversification, and thus Serb hegemony. ${ }^{72}$

${ }^{67}$ Census 1870, 56, 60; https://library.hungaricana.hu/hu/view/NEDA_1870/?pg= $135 \&$ layout $=s$ [Accessed: 29 June 2019].

${ }^{68}$ Concerning the suffrage in the city municipalities, see footnote no. 52.

${ }^{69}$ Census 1881, 29.

${ }^{70}$ In November 1861, the emperor once again suspended the constitution, the National Assembly and the self-governance of municipalities and ruled by decrees. Municipal officers were appointed by the central administration, namely the monarch's Royal Chancery and the Royal Hungarian Lieutenancy. Only after the restoration of the parliament (1865, its first Acts were sanctioned from 1867) the responsible government (formed: February 1867) took measures in order to hold assembly- and council elections, by first summoning the 1861 representatives and council elections were conducted by the current officials, 'inherited' from the pre-1867 regime.

${ }^{71}$ Deák 2017, 278.

${ }^{72}$ Letter from the Hungarian voters to the Interior Minister (25 March 1867), MNL K148 Bm. elnöki iratok III.65-2067; letter from the Interior Minister to 
Consequently, the Serb-dominated assembly elected Svetozar Miletić, the most prominent figure of the national movement ${ }^{73}$ as mayor, together with other officials (nearly all were Serbs). ${ }^{74}$

The distress between the Hungarian-German and Serb parties grew rapidly after the council elections. Miletić kept Serbian as the official language of the municipality, which was instituted during his first mandate as mayor in 1861 and was the subject of the Hungarian complaint of 1867. New complaints were handed to the Interior Minister against the new municipal leadership, stating that Miletić had 'instigated nationalistic tensions' by presenting agitating speeches against the government, with references to the Serbo-Hungarian civil war of 1848-9; promoted the reestablishment of the Voivodship; misappropriated the finances of the municipality; and quartered 'subjects of bad reputation' - Serbian emigrés accused of Pan-Slavic agitations who hoisted the national flag of the Serbs on the city hall and ignored governmental regulations. ${ }^{75}$ On top of all that, the investigation in Belgrade following the assassination of the Serbian monarch Mihailo Obrenović (1839-42, 1860-8) on 10 June 1868 led to the discovery of a conspiracy stretching to Hungary, with the alleged participation of some members of the Zastava, Miletić's newspaper. This provided the ultimate reason (backed by an international request from the Belgrade government) for the Interior Minister to appoint a governmental commissioner

György Kondorossy, president of the electoral board (25 March 1867), MNL K148 Bm. elnöki iratok III.65-206.

${ }^{73}$ Svetozar Miletić (1826-1901) was a leading influential Serb politician in Hungary, also called the 'Serb Mazzini' by his fellow politician, Nikola Milutinović. He was head of the daily newspaper, Zastava, mayor of Újvidék (1861-2, 1867-8) and member of Parliament through several elections from 1865, and leader of the Serb National Liberal Party founded in 1869. He was later incarcerated in 1876-9. See Gábor G. Kemény: A magyar nemzetiségi kérdés története I. rész - A nemzetiségi kérdés a törvények és tervezetek tükrében 1790-1918 [The history of the Hungarian nationality question, Part I: The nationality question in the aspect of acts and drafts 1790-1918] (Budapest, 1947), 140.

${ }^{74}$ Deák 2017, 278.

${ }^{75}$ Interpellation of the Interior Minister in the Hungarian National Assembly by the voters of Újvidék (21 July 1868), Képviselóházi napló, 1865, ix (Register of the House of Representatives, 1865), 221-35; https://library.hungaricana.hu/hu/ view/OGYK_KN-1865_09/?pg=220\&layout=s [Accessed: 29 June 2019]; letter from Nándor Ast, governmental commissioner to the Interior Minister (22 Aug. 1868), MNL K148 Bm. elnöki iratok, III.15053; letter from Nándor Ast, governmental commissioner to the Interior Minister (3 July 1868), MNL K148 Bm. elnöki iratok, III.1505. 
to Újvidék. Commissioner Nándor Ast was ordered to investigate suspected conspirators, including Miletić; govern the municipality in order to 'readjust the city administration'; and to examine the reasons behind the complaints against the municipality officials. The commissioner was authorised to order arrests, suspend and appoint city officials, and if necessary use the forces of the imperial (k.u.k.) army. ${ }^{76}$

Ast arrived in the city on 26 June and promptly arrested two conspirators. Based on their testimonies incriminating Miletić, the commissioner suspended the mayor from his office four days later. However the subsequent evidence from the testimonies was deemed insufficient to charge Miletić ${ }^{77}$ - there was no evidence against him as being one of the conspirators, and his agitation speeches were found to be intimidating, but not legally subversive. Thus the main reasons underlying the commissioner's action were based on Miletićs municipal policy. The city assembly resisted the commissioner even before the suspension of Miletić, stating that such authorisation violated the municipal constitutional autonomy, especially the suspension and appointment of its officials, denied the presence of any disorder in the city and considered a parliamentary interpellation of the Interior Minister. After the appointment of a new mayor (Pál Stojanovics) by the commissioner, the struggle escalated. The assembly resisted by electing a third person as mayor and issuing a vote of confidence in Miletić, and boycotted the inauguration session of the commissioner's mayor. ${ }^{78}$

Ast still found Miletić to be dangerous, considering the strength of his Serb party, which still held the most important positions, and thus suggested to the Interior Minister to have the National Assembly suspend Miletić's immunity (Miletić was a member of parliament since

${ }^{76}$ Interpellation of the Interior Minister in the Hungarian National Assembly by voters of Újvidék (21 July 1868), Képviselóházi napló, 1865, ix, 221-35; https:// library.hungaricana.hu/hu/view/OGYK_KN-1865_09/?pg =220\&layout=s [Accessed: 29 June 2019]; appointment letter from the Interior Minister to Ast (20 June 1868), MNL K148 Bm. elnöki iratok, III.1505.

${ }^{77}$ Miletić - bearing legal immunity as a member of Parliament - allowed the investigation against himself on $25 \mathrm{July}$, which the House accepted on $30 \mathrm{July}$, Képviselöházi Irományok, 1865, v, 194; https://library.hungaricana.hu/hu/view/ OGYK_KI-1865_05/?pg=201\&layout=s [Accessed: 21 Nov. 2019]; Képviselóházi napló, 1865, ix, 287-8; https://library.hungaricana.hu/hu/view/OGYK_KI1865_05/?pg=201\&layout $=$ s [Accessed: 21 Nov. 2019].

${ }^{78}$ Letter from Ast to the Interior Minister (3 July 1868), MNL K148 Bm. elnöki iratok, III.1505. 
1865, elected by a small communal district of Bács-Bodrog county) ${ }^{79}$ and dissolve the municipal assembly. Ast's ultimate argument supporting security measures was political. He argued that if the government did not help the German and Hungarian communities, sided with the governing party, on the one hand, the government would lose them as supporters, and on the other, the Catholics might adopt violent measures to solve the problem. The Interior Minister did not agree to seek the suspension of Miletićs immunity, but agreed to dissolve the city assembly and the council so that they would not sabotage the actions of the commissioner. With this new authorisation menacing the municipality, Ast managed to make the assembly and the council agree to revoke its previous resolutions and to recognise the appointed mayor, acknowledging the new status quo on 18 July ${ }^{80}$

The interpellations of the Interior Minister in the House of Representatives were unsuccessful. Even though the minister acknowledged that his actions were unconstitutional, he stated that they were justified by the state of emergency and lack of public order, which was the result of the actions of the municipality administration. Miletić was cheered by the Serb population on his route through southern Hungary. The 'flag affair' was later concluded with a ministerial ban on the Serbian national flag, referring to Act XXI of 1848 (Act on the national colours and coat of arms), which allowed for the prohibition of any state/ national flag other than the Hungarian on public buildings. ${ }^{81}$

Following the summer of conflicts in Ujvidék, Ast still reported some continuing acts of resistance the same year on the part of the city administration and against the governmental regulations (for example, forwarding municipal protocols to the government only in Serbian), ${ }^{82}$ but the governmental policy at that time was to maintain order and

${ }^{79}$ For more on the 1865 parliamentary elections, see József Ruszoly, Országgyúlési képviseló-választások Magyarországon 1861-1865 [Parliamentary elections in Hungary 1861-1865] (Szeged, 1999) (hereinafter: Ruszoly 1999).

${ }^{80}$ Convolutum regarding Ast's actions in Újvidék, MNL K148 Bm. elnöki iratok, III.1505, 133-55.

${ }^{81}$ Petition from the Serbs of Újvidék to the Interior Minister (26 Aug. 1868), MNL K148, Bm. elnöki iratok III.1505; letter from the Interior Minister to Ast (29 Aug. 1868), MNL K148 Bm. elnöki iratok, III.1505; letter from the Interior Minister to Ast (18 Sept. 1868), MNL K148 Bm. elnöki iratok, III.1505.

${ }^{82}$ Convolutum regarding Ast's actions in Újvidék, MNL K148 Bm. elnöki iratok, III.1505, 133-55. 
keep the tensions low until the new epoch-making codices were drafted in the National Assembly in Pest. The new regulations to standardise the municipalities were meant to be a settlement covering the whole Dualistic era. The Nationality Act (in effect from 24 December 1868) was primarily a language law and the Municipality Act (in effect from 1 January 1872, although the government executed the Act in December 1871 by ordering municipal elections according to the new regulations) drastically changed the structure of the municipal organs..$^{83}$ From 1872 on, only half of the assembly members were elected, with extended suffrage for 8-10 per cent of the population, while the other half consisted of the highest taxpayers, with some privileged status for the intelligentsia. The Act also secured the central administration's direct influence in the councils, by granting the right to nominate candidates for offices to an electoral board consisting of seven members of the assembly: the Lord-Lieutenant of the city, three members chosen by the Lord-Lieutenant, and three elected by the assembly.

However, the upcoming elections for the reformed municipal assemblies foreshadowed tensions similar to those of 1868. In 1871, Miletić who controversially won the parliamentary election in 1869 , this time in the Újvidék electoral district ${ }^{84}$ - was the target of a criminal procedure once again and was arrested on charges of libel. Demonstrations in Újvidék followed his arrest. ${ }^{85}$ The protesters declared their 'national rights' to have been violated and demanded the release of Miletić; otherwise, they would not consider the state as rightful and just. ${ }^{86}$

${ }^{83}$ Letter from the Interior Minister to the municipalities (15 May 1871), MNL K148, Bm. elnöki iratok III.1083).

${ }^{84}$ Along with another district's mandate from another municipality east of Bács-Bodrog county. József Ruszoly, Országgyülési képviselö-választások Magyarárszágon 1869-1874 [Parliamentary elections in Hungary 1869-1874] (Szeged, 2013) (hereinafter: Ruszoly 2013), 160-70, 447-9; Tamás Antal: 'Országgyűlési képviselők választókerületenként (1869-1875)' [Members of Parliament by electoral districts 1869-1875], in Ruszoly 2013, 625-55.

${ }^{85}$ According to the Újvidék mayor's report, Miletić wrote problematic articles in the newspaper Zastava against the Ban (the executive head of the autonomous Croatia-Slavonia, appointed by the Hungarian Government and the King, responsible for both the Hungarian Government and the Zagreb sabor), stating that he turned the sabor against the Cyrillica.

${ }^{86}$ Letter from the deputy captain of Újvidék to the mayor, 1 April 1871 (MNL OL K148 Bm. elnöki iratok, XIV.678 678); letter from the mayor to the Interior Minister, 3 April 1871 (MNL OL K148 Bm. elnöki iratok, XIV.678 736). 
An orator from Belgrade, a (non-identified) officer, claimed the same concerns about Miletić in the name of the 'Transsavians', emphasising to the world that the Serbs were not 'old women' ${ }^{87}$ The demonstrators in their announcement placard claimed that the 'uprising' of the 'Voivodina Serbs' had a peaceful and legal nature and that their weapons were free speech and free assembly. The mayor reacted cautiously by allowing the demonstration - although commanding the use of police and military force if necessary - which in turn resulted in the indignation of the Ministry of the Interior, whose head ex post facto viewed the demonstration as anti-constitutional, anti-Hungarian and as a tool aimed at inflaming tensions, which should have been banned by the mayor after the public announcement. The minister even asked the minister of religion and education to take measures against a teacher of a statefunded city lyceum and his pupils, who had gathered with the crowd. ${ }^{88}$

Versec is the only case among the examined cities where the Roman Catholics had an absolute majority (55 per cent) against the Serbs/ Orthodoxy (40 per cent) according to the 1870 census, ${ }^{89}$ hence providing an inverse situation to that of Újvidék. However, what made the case of Versec special is that the governance found a juste milieu on two occasions when the rotation was at issue by the local politicians. The city was founded in 1804 through the unification of a German and a Serb commune; therefore, an agreement on the division of the city council was plausible. The parity was restored by the central government after the exceptional times of the Voivodship in 1861, although, after complaints against the Roman Catholic German mayor in 1863, the Royal Hungarian Lieutenancy appointed a non-resident Croatian to the office. ${ }^{90}$ The 1865 National Assembly elections showed signs of the parity, as the electoral board was divided by the municipal council

${ }^{87}$ Letter from the deputy captain to the mayor, 4 April 1871 (MNL OL K148 Bm. elnöki iratok, XIV.678 53).

${ }^{88}$ Letter from the Interior Minister to the mayor, 19 April 1871 (MNL OL K148 Bm. elnöki iratok, XIV.757); letter from the Interior Minister to the Minister of Religion and Education, 19 April 1871 (MNL OL Bm. elnöki iratok, XIV.757; Convolutum regarding the demonstrations, 25 April 1871 (MNL OL, XIV.678).

${ }^{89}$ Census 1870, 60; https://library.hungaricana.hu/hu/view/NEDA_1870/?pg= $135 \&$ layout $=s$ [Accessed: 29 June 2019]; letter from the mayor to the Interior Minister, 5 April 1871 (MNL OL K148 Bm. elnöki iratok, XIV.678).

${ }^{90}$ Deák 2017, 283. 
between Serbs and Germans. The two parties both complained against each other's misuse of voter registration and the Serb candidate won against the Hungarian by a slim 1027-1996 majority. Though the elections were illegally cut into two phases by a night rest, the House of Representatives accepted the mandate out of 'discretion towards nationalities' ${ }^{91}$

On the eve of the new city assembly and council elections of 1867 , the Serb minority addressed a petition to the Interior Minister, charging the president of the electoral board with alignment with the German party and putting an end to the division of the offices. They asked the minister to send a government commissioner to proportionally appoint Serb council members instead of Germans, citing such a custom in other cities. ${ }^{92}$ While the minister postponed the elections - as the Serbs asked - the 'Hungarian affiliated' Hungarian and German voters formulated a counter-petition, denying that such a custom existed after 1861 due to the lack of any agreement. They argued against the division because they claimed to have suffered from unjust treatment during the Serb leadership of the Voivodship; that the rotation was sometimes even corrupted by re-elections; that such a division was against a professional administration (an argument recalling the case of Zombor); and that they never could have had any intention of making such a division while possessing a majority within the population, the landowners, the voters and taxpayers. ${ }^{93}$ The president of the electoral board suggested a reduced version of powersharing in the council elections: i.e. that the mayor's office should be subject to a free election with candidates from both parties, while the outcome of that election would determine the national division of the rest of the offices, using a decreasing hierarchy of importance after the mayor. Thus if a Serb were to be elected as mayor, the next

${ }^{91}$ Ruszoly 1999, 411; Képviselóházi napló, 1865, i (Register of the House of Representatives, 1865), 114; https://library.hungaricana.hu/hu/view/OGYK_KN1865_01/?pg=113\&layout $=$ s\&query=versec [Accessed: 29 June 2019].

${ }^{92}$ Petition from Serbs of Versec to the Interior Minister (13 May 1867), MNL K148 Bm. elnöki iratok, III, 65-1934.

${ }_{93}$ Petition from German and Hungarian voters (and also a few Serbs, indicated by the Serbian Cyrillic signatures among the signatories of Versec) to the Interior Minister (19 May 1867), MNL K148 Bm. elnöki iratok III, 865-2047; letter from Ferenc Grausam, president of the electoral board to the Interior Minister (19 May 1867), MNL K148 Bm. elnöki iratok III, 865-2047. 
official would be elected from among the Catholics, and so on and vice versa. ${ }^{94}$

The elections seemed to have been conducted in this manner; thus, the assembly majority elected a German for mayor, a Serb for the next office, and so forth. The minister nonetheless sent a governmental commissioner in response to another Serb petition, which asked to supervise the registration of voters, arguing that if only one part of the city had disposition over the common properties and affairs, the 'nothing about us, without us' principle would have been breached. The commissioner however didn't play such an important role as in the case of Újvidék. ${ }^{95}$

Tensions between the two communities arose again in 1868 when a 'honvéd'-aid ball was held by the Germans commemorating the fallen soldiers of Hungary ('honvéds') in the Independence war of 1848-9. ${ }^{96}$ As a counter-demonstration, the Serbs offered a requiem, with political speeches for their 'fallen' of the same war - the former enemies of the 'honvéds'. The matter reached the ministry, which commanded the Lord-Lieutenant of the neighbouring Temes county to keep an eye on the national movements in the area, with the help of financial funds and a 'confidential staff' (possibly informants). ${ }^{97}$

In all of the cities mentioned above, originally, the religious groups were the holders of collective rights. However, over time national identification surpassed religious affiliation in importance, thus transforming these groups into national communities. This transformation coincided with annulment by the state of the old 'feudal' privileges of the municipal councils, thus paving the way for political modernisation

${ }^{94}$ Letter from Ferenc Grausam, president of the electoral board to the Interior Minister (19 May 1867), MNL K148 Bm. elnöki iratok III, 865-2047.

${ }^{95}$ Deák 2017, 286. Petition of Serb representatives of Versec to the Interior Minister (5 Sept. 1867), MNL K148 Bm elnöki iratok III, 65-2648.

96 The Versec Germans, along with some other German ethnic enclaves (but unlike the Saxons of Transylvania), had fought on the Hungarian side, in the 'honvéd army', during the 1848-9 war. For more on ethnic characteristics and atmosphere of the city, see Herceg Ferenc emlékezései. A várhegy [The reminiscence of Ferenc Herceg] (Budapest, 1933), 31-4.

${ }^{97}$ Letter from the Versec district, district administrator to the Interior Minister (20 Feb. 1868), MNL K148 Bm. elnöki iratok IV.464; letter from the Lord-Lieutenant of Temes to the Interior Minister (29 Feb. 1868), MNL K148 Bm. elnöki iratok IV.464. 
based on legal equality - in this sense we cannot consider it a general counter-securitisation move against the respective groups.

In all three cases the religious-national parties wanted to secure their positions and keep the old system of parity, which had minorities in the city council: in Zombor and Újvidék the Hungarian, German (and Bunjevci) Catholics; while in Versec the Orthodox Serbs. The primary policy of the Interior Ministry of the Andrássy cabinet was to keep the nationalist tensions low and maintain public order, and to calm and avoid further struggles between the national groups. Therefore the new Hungarian liberal government did not favour one community against another. The governmental interventions stuck to the legality of each situation, thus abandoning the parity power-sharing system in the cases of Zombor and Újvidék, which indirectly favoured the Serbian party at the councils. The system was only kept intact in Versec, which shared the council offices (except for the mayor's), and thereby curbed the Catholic majority. Although orders were given to Zombor's government commissioner to use 'influence' at the elections and the Serb mayor of Újvidék was discharged, there were no drastic changes in the city offices in favour of the Hungarian character of the municipalities. This temporary period ended shortly after with the Nationality and Municipality Acts, securing governmental influence in the city councils and de iure allowing space for local languages in municipalities.

\section{IV \\ CONCLUSIONS}

A political regime-change is always a challenge to local elites, who need to secure their leading positions in a new system of institutions and a new legal order. Local elites might need to transform local power relations, primarily when sharply distinct communities reside side by side. The case studies show, for example, how national elites could hold their ranks against central power. Until 1848, the guarding of municipal autonomy from state centralisation was unquestionably a (Hungarian) national program: municipal autonomy in the counties was defended as the most important tool to avoid the further incorporation of Hungary into the Habsburg Empire. After entering the Era of the Dualism, the municipalist-centralist struggle had a completely different context, losing its aspect of defending Hungarian (partial) 
independence, although the opposition party still aimed to keep this function to confront the Compromise.

The above-examined regions had multiple security issues: the betyárs, the Roma population, Catholic political opposition, anti-Semitism, local elections, and nationalistic municipal parties. The local elites of the respective groups played a crucial role as security actors; in the case of nationality groups - which affected both the western and southern regions explored herein - both the state's and some of those societies' security became an issue. National groups deemed the 'rule' of the other as a threat to their national community, for example objecting to a one-sided usage of the official language, against national symbols and the establishment of national cultural institutions. The state, on the other hand, recognised these issues as security risks, which is clearly demonstrated by the measures taken (appointing a government commissioner). Still, the state did not play the role of a security actor in each and every instance. When the only threat the state faced from tensions between rival groups in the municipalities was low public order and safety, it tended to try to pacify the tensions by playing the role of mediator rather than that of an actor.

The antagonism between local nationality elites culminated after the 1867 Compromise, which led them all to seek to secure a favourable position. Our two case studies differ here not only geographically, but also in terms of their historical perspective. The first attempts to provide an overview of security challenges of the entire Dualist era, while the second digs deeper into the most critical issue at the time; namely the nationality question in the very first years after the Compromise. In our research, we have combined these regions by examining the most crucial security issues on the eve of the modern, self-governing Hungarian state. The main difference between western and southern Hungary in this matter is that in the western part the nationalist conflict was just one of the series of smaller or larger security issues brought about as modern times raised new challenges to the local elites, and it only escalated at the end of the Austro-Hungarian era, while in the south, already in 1867-8 nationalistic conflicts overshadowed all other struggles. 


\section{SELECTED BIBLIOGRAPHY}

Baumgartner Gerhard, 'Die National Differenzierungsprozess in den ländlichen Gemeinden des südlichen Burgenlandes', in Andreas Moritsch (ed.), Vom Ethnos zu Nationalität. Der nationale Differenzierungsprozess am Beispiel ausgewählter Orte in Kärnten und Burgenland (Wien-München, 1991), 93-155.

Buzan Barry, Waever Ole, and de Wilde Jaap, Security - A New Framework for Analysis (London, 1998).

Conze Eckart, 'Securitization. Gegenwartsdiagnose oder historischer Analyseansatz?', Geschichte und Gesellschaft, 38 (2012), 453-67.

Csibi Norbert and Schwarczwölder Ádám (eds), Modernizáció és nemzetállam-épités. Haza és/vagy haladás dilemmája a dualizmus kori Magyarországon [Modernisation and nation-state building. The dilemma of patria and/or progress in Hungary in the era of dualism] (Pécs, 2018).

Csiky Károly, A magyar állam közigazgatási joga [Public Administration Law of the Hungarian State], i (Budapest, 1899).

Csizmadia Andor, A magyar közigazgatás fejlödése a XVIII. századtól a tanácsrendszer létrejöttéig [The Development of Hungarian Public Administration from the 18th Century to the Establishment of Soviet System] (Budapest, 1976).

Deák Ágnes, “"Mindenkor mindent nemzetiség kérdésévé tesznek”: Helyhatósági választások etnikai, felekezeti és nemzetiségi választó vonalak erőterében (1867)' ["They always make everything a matter of nationality": Municipal elections in the context of ethnical, religious and nationality lines, 1867], in Zita Horváth and János Rada (eds), Társadalomtörténeti Tanulmányok Tóth Zoltán emlékére (Miskolc, 2017), 273-92.

Gerő András, The Hungarian Parliament (1867-1918): A Mirage of Power (New York, 1997).

Lojkó Miklós (ed.), Hungary’s Long Nineteenth Century. Collected Studies by László Péter (Leiden-Boston, 2012).

Péter László, 'Central Europe and its reading into the past', European Review of History, vi, 1 (1999), 101-11.

Péter László, 'Die Verfassungsentwicklung in Ungarn', in Helmut Rumpler and Peter Urbanitsch (eds), Die Habsburgermonarchie 1848-1918, vii, 1: Verfassung und Parlamentarismus (Wien, 2000), 239-540.

Sarlós Béla, Közigazgatás és hatalompolitika a dualizmus rendszerében [Public administration and power politics in the system of the dualism] (Budapest, 1976).

Stipta István, Die vertikale Gewaltentrennung (Budapest, 2005).

Zwierlein Cornel, 'Sicherheitsgeschichte. Ein neues Feld der Geschichtswissenschaften', Geschichte und Gesellschaft, 38 (2012), 365-86.

Tamás Székely - Austro-Hungarian Monarchy history, with special focus on nationalism and security studies; research fellow at Herder Institute (Marburg), $\mathrm{PhD}$ candidate at Pázmány Péter Catholic University and at the Philipps University of Marburg (co-tutelle); e-mail: tamas.szekely@herder-institut.de 
Szilveszter Csernus-Lukács - late 19th-century Habsburg history, with special focus on security, nationalism and national minorities; research fellow at Herder Institute (Marburg), PhD candidate at the University of Szeged and at the Philipps University of Marburg (co-tutelle); e-mail: szilveszter.csernuslukacs@herderinstitut.de 